\title{
Reduced Streamflow Lowers Dry-Season Growth of Rainbow Trout in a Small Stream
}

\author{
Bret C. Harvey, * Rodney J. Nakamoto, and Jason L. White \\ U.S. Forest Service, Pacific Southwest Research Station, 1700 Bayview Drive, Arcata, California 95521, USA
}

\begin{abstract}
A wide variety of resource management activities can affect surface discharge in small streams. Often, the effects of variation in streamflow on fish survival and growth can be difficult to estimate because of possible confounding with the effects of other variables, such as water temperature and fish density. We measured the effect of streamflow on survival and growth of rainbow trout Oncorhynchus mykiss in a small stream in northwestern California by manipulating the flow entering four of eight enclosed stream sections (9.0-15.3 m long) containing one pool and 2.5-4.0 $\mathrm{m}$ of upstream riffle habitat. In the four manipulated experimental units, we reduced inflow by $75-80 \%$ over a 6 -week period in summer 2003 . Flow diversion substantially decreased water velocity in riffle-pool transition areas but did not strongly affect habitat volume or water temperature. Fish in control units grew about 8.5 times as much as those in units with reduced streamflow; however, discharge manipulation did not affect survival, which exceeded $90 \%$ in both treatments. The input of invertebrate drift to pools within control units greatly exceeded the input into units with reduced streamflow; the concentrations of drifting invertebrates differed to a lesser extent between control and manipulated units. Managers concerned about salmonid populations in small streams should consider dryseason streamflow to be a key variable affecting fish growth.
\end{abstract}

Resource managers can influence the surface flow of rivers and streams directly through the operation of dams and diversions or indirectly through activities that affect stream channel aggradation, interception loss of precipitation, and evapotranspiration. Managers of large, regulated rivers have long considered the consequences of variation in stream discharge for fish, but the influence of discharge magnitude on fish in small streams has received relatively little attention. The tight linkage of processes between hillslopes and small streams (Gomi et al. 2002) creates the potential for significant anthropogenic changes in the flow of small streams even in the absence of dams and largescale diversions; alteration of dry-season flow in response to changes in vegetation (Keppeler and Ziemer 1990; Hicks et al. 1991) provides an example of this. Better understanding of any linkages between stream discharge and the rates of processes affecting fish populations in small streams should be valuable, given that small streams make up a large proportion of stream networks and may provide refuges for populations of special concern (Novinger and Rahel 2003).

Variation in discharge during seasonally low flows may affect fish by several mechanisms. Complete loss of habitat units in intermittent streams can be an important source of mortality in some settings (May and Lee 2004). Less dramatic habitat changes may also

\section{* Corresponding author: bch3@humboldt.edu}

Received September 26, 2005; accepted February 7, 2006 Published online July 20, 2006 influence survival and growth. For example, lower discharge commonly reduces the area or volume of habitat units without eliminating them (Hakala and Hartman 2004). Variation in stream discharge may alter physicochemical conditions, such as dissolved oxygen concentration, which can influence fish growth (Guyette and Rabeni 1995). Lower stream discharge may increase predation risk (Heggenes and Borgstrøm 1988) through changes in water depth (Harvey and Stewart 1991) and water velocity. Lower stream discharge can also reduce foraging opportunities for drift-feeding fish in small streams during seasons with low streamflow (Nislow et al. 2004). Although the relationship between capture success and water velocity is unimodal for drift-feeding trout (Hill and Grossman 1993), microhabitats with water velocities that are too high for efficient prey capture by salmonids probably remain rare, even at relatively high dryseason discharge levels in small streams. Finally, lower streamflow might also affect fish growth by altering autochthonous secondary production and the delivery of litter and invertebrates from riparian zones.

Several of these mechanisms may contribute to the patterns in growth of salmonid fishes observed in natural systems. For example, annual variation in growth of adult Arctic grayling Thymallus arcticus in an Alaska river correlated positively with mean summer discharge (Deegan et al. 1999). In two California streams, summer growth of rainbow trout Oncorhynchus mykiss was positively related to distance downstream (Harvey 1998; Harvey et al. 2005) and 
thus indirectly to streamflow, where factors other than discharge were either included in the analyses or were not highly variable. In a tributary of the Connecticut River, variation in growth of Atlantic salmon Salmo salar corresponded to streamflow-driven changes in the estimated availability of foraging habitat, although growth was also correlated with fish density (Nislow et al. 2004).

As these examples illustrate, one challenge in measuring the effects of discharge variation on fish is that natural variation in discharge is often confounded with variation in fish density and with changes in other physical variables, such as water temperature. In this study, our objective was to measure the effect of streamflow on the survival and growth of a stream salmonid (rainbow trout) by use of a manipulative field experiment that reduced the influence of confounding variables.

\section{Study Area}

We conducted this study in Jacoby Creek, a coastal stream in northwestern California that drains a catchment dominated by second-growth forest. At the study reach, Jacoby Creek is a second-order stream with a $1.7 \%$ gradient and drains about $12 \mathrm{~km}^{2}$. Red alder Alnus rubra and bigleaf maple Acer macrophyllum are the most common riparian trees, whereas stink currant Ribes bracteosum, western elderberry Sambucus caerulea, and thimbleberry Rubus parviflorus dominate the riparian understory. Poorly sorted gravel and small cobble dominate the substrate. Streamflow declined from 30 to $15 \mathrm{~L} / \mathrm{s}$ during the experiment from 19 July to 4 September 2003. The range of water temperature, recorded every $1.2 \mathrm{~h}$ by data loggers placed at shaded, well-mixed sites, was $11.2-15.2^{\circ} \mathrm{C}$ across all experimental units during the study, whereas the range of mean temperatures within experimental units was $12.4-13.1^{\circ} \mathrm{C}$. Native rainbow trout are the only fish in the study reach.

\section{Methods}

The eight experimental units for this study were individual stream pools with adjoining sections of upstream riffle $(2.5-4.0 \mathrm{~m})$ enclosed by cross-stream fences of 6-mm-mesh plastic screen supported by metal stakes. The eight units averaged $12.0 \mathrm{~m}$ in length $($ range $=9.0-15.3 \mathrm{~m})$ and $34.0 \mathrm{~m}^{2}$ in area (range $=$ $28.3-41.7 \mathrm{~m}^{2}$ ) at the start of the experiment. A mean stream length of $41 \mathrm{~m}$ separated the units; stream sections between units included pools that contained fish, which we assumed would eliminate any influence of upstream treatments on experimental units. All units offered substantial cover for fish in the form of woody debris, unembedded boulders, or undercut banks. We randomly assigned experimental units to treatments to yield four units with unaltered streamflow and four with the majority of flow diverted in three $15.2-\mathrm{cm}$ diameter, flexible plastic pipes. The three pipes were forced through openings in the plastic screen of the upstream enclosure fence and positioned about $2 \mathrm{~cm}$ off the bottom near the center of the stream. Pipes were separated by about $1.5 \mathrm{~cm}$ at the upstream enclosure fence. We directed the pipes from the upstream enclosure fence to the stream bank, along the stream bank, then back into the stream to return water 1-2 m downstream of the lower enclosure fence. Pipes were supported above the water surface by exposed cobbles in the upstream riffle along the $0.5-1.0-\mathrm{m}$ distance from the upstream fence to the stream bank. Upstream of the enclosures, flow was directed toward the diversion pipes by $\mathrm{V}$-shaped gravel berms that reduced stream width by approximately $50 \%$ (Figure 1).

To characterize the physical environment within experimental units, we subdivided each unit into five to nine cells, delineating these to contain areas of relatively homogeneous water depth and velocity. One cell in each unit contained the upstream riffle, and one represented the head of the pool. Usually one cell, and at most two cells, covered the entire stream width. Just before manipulation of the diverted units, and on three dates afterward, we measured the width of these cells and the depth and velocity at three equally spaced points along a cross-stream transect through the middle of each cell. We also measured discharge through each unit on these four dates and on one additional date during the experiment.

We measured fish survival and growth by mark and recapture. Fish older than age 0 were first collected by multiple-pass electrofishing after fences were installed. Fish were anesthetized, measured to the nearest $1 \mathrm{~mm}$ fork length (FL), weighed to the nearest $0.01 \mathrm{~g}$ on an electronic balance, and then implanted with passive integrated transponder (PIT) tags, which allowed us to identify individuals. At the end of the experiment, fish were collected, identified, measured, and weighed by means of the same methods and apparatus. We also used gastric lavage to collect diet samples from all fish older than age 0 recovered from the experimental units. Laboratory processing of the diet samples included identification, enumeration, and measurement of invertebrates by use of a dissecting microscope with an ocular micrometer. We converted body lengths of individual prey to estimates of dry mass based on taxon-specific relationships provided by K. W. Cummins and M. A. Wilzbach (Humboldt State University Institute for River Ecosystems and U.S. Geological Survey California Cooperative Fishery Research Unit). Age-0 fish were not included in our measurements 


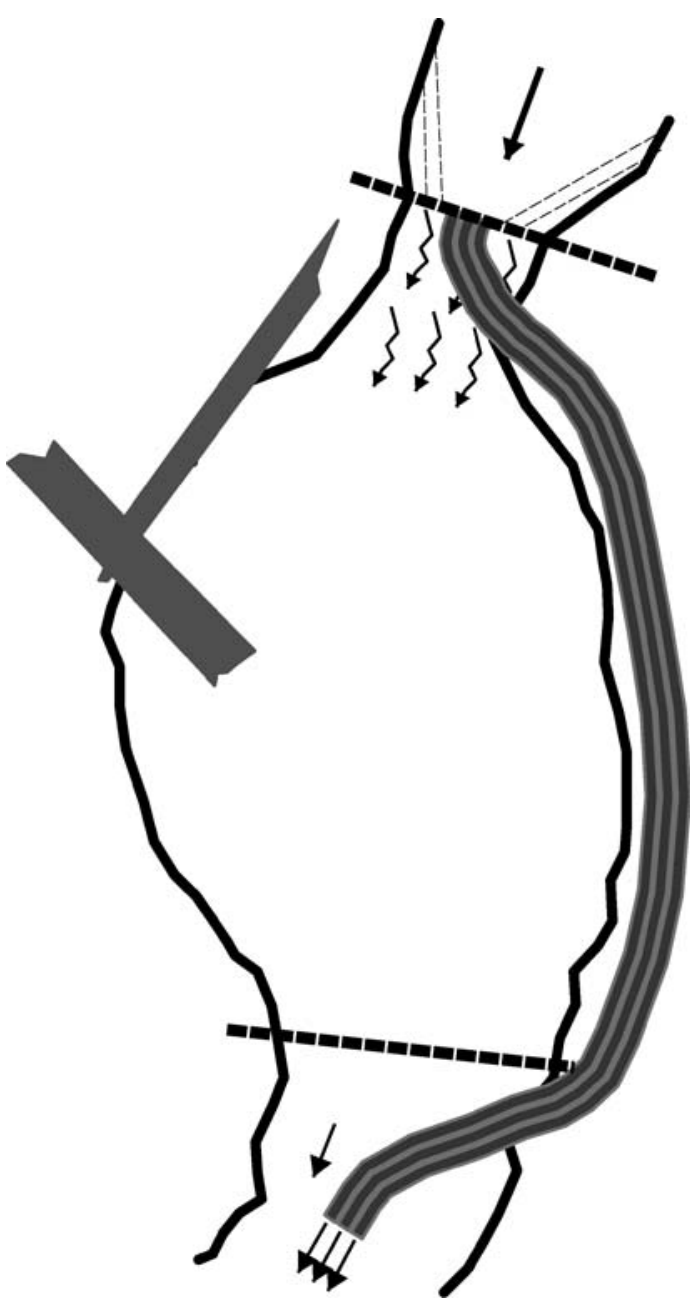

Figure 1.-Diagram of an upper Jacoby Creek, California, experimental unit with streamflow partially diverted into three 15.2-cm-diameter plastic pipes. Heavy dotted lines indicate cross-stream fences of 6-mm plastic mesh.

because they were not large enough to receive PIT tags, were unlikely to be contained by the enclosure fences at the beginning of the experiment, and contributed a small fraction of total fish biomass.

In addition to measuring survival and growth, we also estimated total caloric consumption based on equations from the Wisconsin bioenergetics model (Hanson et al. 1997) and parameters developed for application of that model to trout (Railsback and Rose 1999). Calories consumed by individual fish were estimated from changes in weight and mean daily temperatures measured in each experimental unit. Because near-zero water velocities predominated in the pools of all experimental units and fish rarely occupied the shallow riffles, we did not include swimming costs in the estimates of calories consumed. When estimating total calories consumed in experimental units where not all fish were recovered, we assumed that missing fish survived for half the experiment and had a growth rate equal to the mean for fish in their experimental unit.

We statistically analyzed both fish growth and calories consumed at the experimental-unit scale by analysis of covariance (ANCOVA). For the analysis of growth, we used mean relative growth of individuals (\% body mass/d) within experimental units as input and the width of the pool head in each unit as the covariate. We included pool head width in the analysis because narrower pool head width is correlated with greater water depth, greater water velocity in feeding zones, or both, which could yield greater opportunities for feeding on drift by pool-dwelling trout. Relative growth data were log-transformed to homogenize variance. Using the same ANCOVA approach, we analyzed calories consumed in units of calories per square meter per day. We did not include fish density in the analyses of growth and calories consumed because a previous experiment in Jacoby Creek suggested that factor would have only a modest effect over the relatively narrow range included in the experiment (Harvey et al. 2005). A posteriori analyses that included diversion treatment, pool head width, and fish density yielded similar results for the first two factors and statistically nonsignificant fish density effects.

To measure the effect of discharge reduction on invertebrate drift inputs, we measured drift in all eight units from $1 \mathrm{~h}$ before to $1 \mathrm{~h}$ after sunset on three dates (26 July, 16 August, and 9 September 2003). We positioned drift nets with $45-\mathrm{cm} \times 30$-cm openings and $363-\mu \mathrm{m}$ mesh to capture the maximum possible streamflow at the riffle-pool transition in each unit. We used an electronic velocity meter with the probe attached to a top-set measuring rod to measure flow through the drift nets; three depth and velocity measurements were made across the mouth of each net. We processed drift samples in the laboratory by the same methods described above for diet samples. We contrasted the concentration and total rate of drift in control versus diverted units with repeated-measures analysis of variance (ANOVA) and used log-transformed data to homogenize variances.

\section{Results}

The diversions reduced flow into the treated units by $75-80 \%$. This change resulted in reduced water velocity in diverted units, particularly at the pool heads, but only small changes in total surface area or 
water depth (Figure 2). The two treatments yielded similar daily mean, maximum, and minimum water temperatures (means: control $=13.0^{\circ} \mathrm{C}$, diverted $=$ $12.7^{\circ} \mathrm{C}$; maximum: control $=13.9^{\circ} \mathrm{C}$, diverted $=$ $13.5^{\circ} \mathrm{C}$; minimum: control $=12.3^{\circ} \mathrm{C}$, diverted $=$ 12. $2^{\circ} \mathrm{C}$; $t$-tests: all $P>0.08$, df $=6$ ).

At the start of the experiment, we captured 10-20 fish older than age 0 (mean age $=13.2$ years, $\mathrm{SE}=1.2$ ) within each experimental unit. Fish initially ranged from 89 to $170 \mathrm{~mm}$ FL and from 7.61 to $55.00 \mathrm{~g}$ in mass. We recorded high survival rates in both control and diverted experimental units over the 48-d experiment, recovering 47 of 52 fish initially tagged in control units and 51 of 54 fish initially tagged in diverted units. At most, two tagged fish were not recovered from any experimental unit; this occurred in one control unit and one diverted unit. Across all eight experimental units at the end of the experiment, we captured a total of six age- 0 fish and no untagged fish older than age 0 .

In contrast to survival, fish growth differed dramatically between treatments (Figure $3 \mathrm{a} ; F_{1,5}=25.4, P=$ 0.004); the width of the pool head also appeared to be important in determining growth $\left(F_{1,5}=6.4, P=\right.$ $0.053)$. Mean relative growth in control units exceeded growth in diverted units by about 8.5 times, while the difference adjusted for the effect of pool head width was 10.6 times. The significance of pool head width was most apparent in the control unit with the widest pool head (3.5 $\mathrm{m}$ versus $1.8-2.6 \mathrm{~m}$ in the other seven units). Relative growth rate averaged $0.09 \% / \mathrm{d}$ in this unit, whereas the range of mean growth in the other three control units was $0.40-0.66 \% / d$. Pool head widths in diverted units ranged from only 2.2 to 2.5 $\mathrm{m}$, providing little opportunity to detect an effect of stream width specifically within that treatment. A contrast between treatments without pool head width as a covariate also indicated a significant effect of diversion on growth $\left(F_{1,6}=11.3, P=0.015\right)$. Inspection of weight change by individual fish within units revealed that although growth by individuals varied more within replicates of the control treatment, unit-specific means were not strongly influenced by any extreme values (Figure 4).

Estimates of calories consumed by fish $\left(\mathrm{cal} \cdot \mathrm{m}^{-2} \cdot \mathrm{d}^{-1}\right)$ also differed between treatments $\left(F_{1,5}=11.5, P=\right.$ $0.020)$, although to a much lesser extent than growth (Figure 3b). Pool head width also influenced calories consumed $\left(F_{1,5}=15.7, P=0.011\right)$. Adjusted for the influence of pool head width, the estimate of calories consumed in control units exceeded the estimate for diverted units by about $27 \%$.
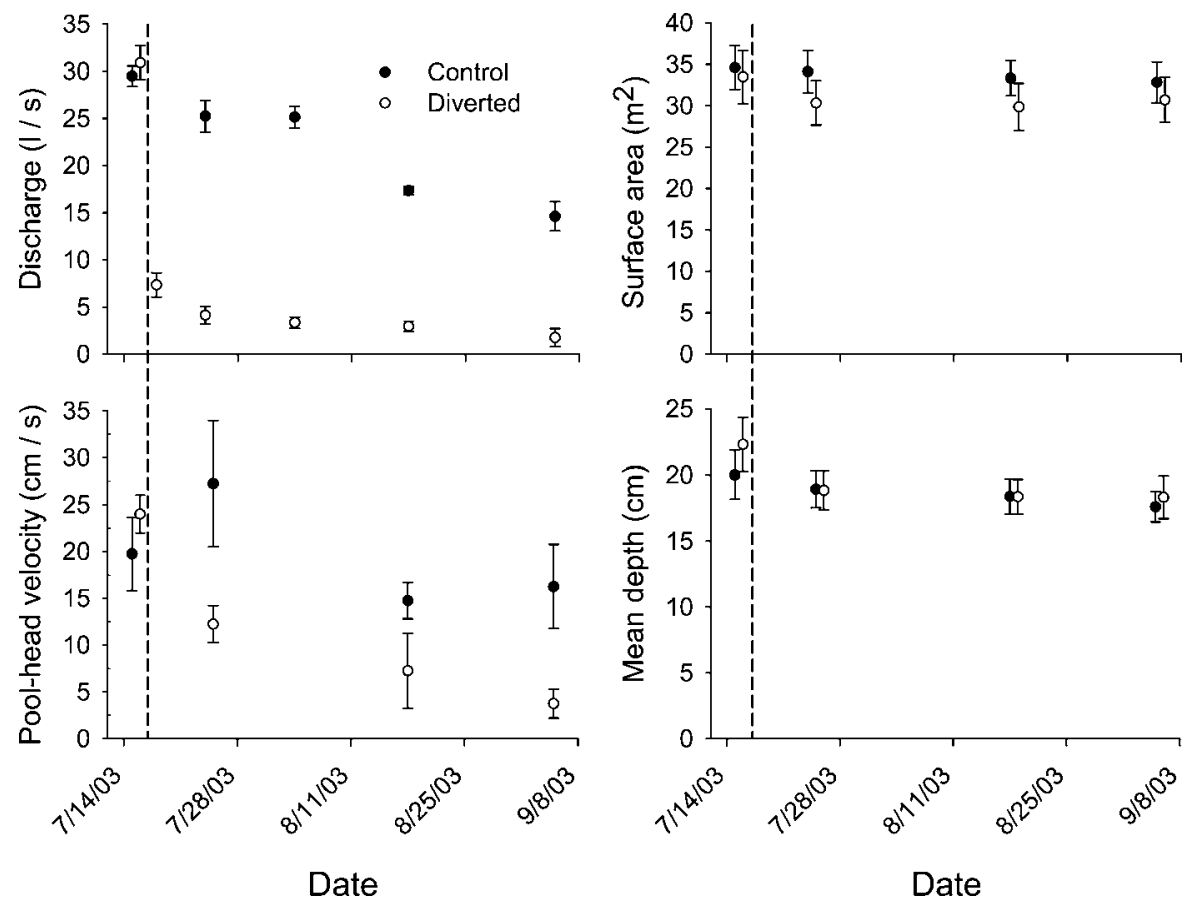

FIGURE 2.-Discharge, pool head water velocity, surface area, and mean depth of control and treatment experimental units in upper Jacoby Creek, California, before and after diversion of streamflow (indicated by the vertical dotted lines). Some points are slightly offset for clarity. Error bars indicate $\pm 1 \mathrm{SE}$. 

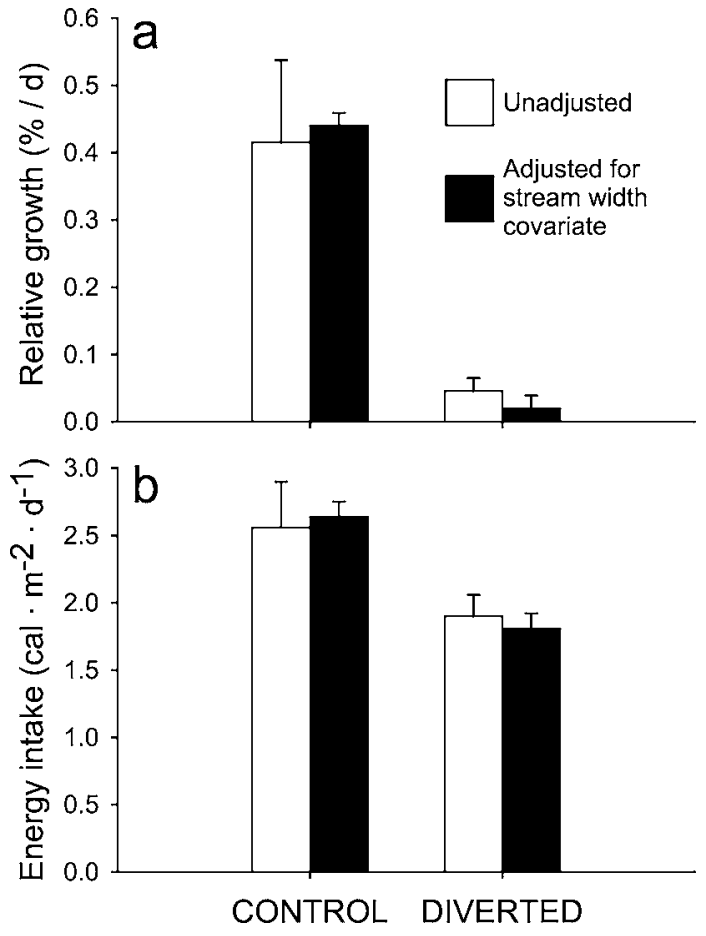

Figure 3.-(a) Relative growth and (b) energy intake by rainbow trout in upper Jacoby Creek, California, stream pools with natural (control) and reduced (diverted) stream discharge. Values reflect the mean results for four experimental units. Unit-specific results for relative growth were determined by averaging the growth of all individuals recovered at the end of the experiment. Error bars indicate $\pm 1 \mathrm{SE}$.

Diversion dramatically reduced the rate of invertebrate drift into pools within experimental units $\left(F_{1,6}=\right.$ 64.6, $P<0.001)$ while reducing drift concentration to a lesser extent $\left(F_{1,6}=6.7, P=0.04\right.$; Figure 5). Although the analyses yielded no statistically detectable influence of date or the date $\times$ treatment interaction (all $P>0.16$ from $F_{2,12}$ tests), both drift rate and concentration declined over the experiment in the control units while remaining relatively stable in diverted units (Figure 5). Diptera and Ephemeroptera were the two most common orders in both control and diverted units, and their contribution to the total mass of the drift did not differ between treatments $(P>0.65$ for both, from $F_{1,6}$ tests). Terrestrial invertebrates made up less than $20 \%$ of total invertebrate biomass in both treatments on all three sampling dates.

As with the results for drift, inspection of the daytime diet samples from the end of the experiment did not reveal any striking differences in composition between treatments. The estimated dry mass of diet samples also did not differ between treatments ( $t$-test:

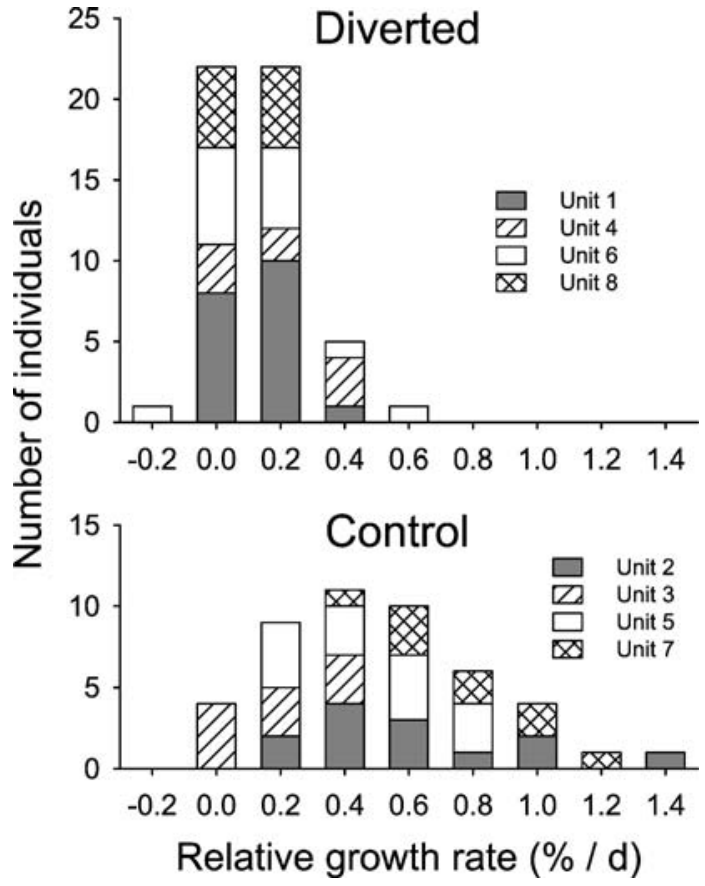

FIGURE 4.-Patterns of individual growth by rainbow trout in upper Jacoby Creek, California, experimental units with natural (control) and reduced (diverted) stream discharge.

df $=6, P=0.68)$ : mean dry mass of gut contents averaged $15.6 \mathrm{mg}$ for fish in control units and $14.3 \mathrm{mg}$ for fish in diverted units.

\section{Discussion}

This experiment indicates that reduced discharge significantly lowered rainbow trout growth in a small stream. Its specific results parallel those from a 10-year data set that related growth of Arctic grayling to annual flow variation and other physical variables in a fourthorder river (Deegan et al. 1999). In Jacoby Creek, a four- to fivefold increase in discharge produced a more than eightfold increase in growth, whereas in the study of arctic grayling (Deegan et al. 1999), the best year for growth of adult fish had 3.7-fold higher mean summer discharge and eightfold higher summer growth than did another study year. One weakness of our experiment is the lack of information on the effects of more modest changes in streamflow. The multiyear data sets presented by Deegan et al. (1999) do not suggest strong nonlinearity in the relationship between streamflow and growth of adult grayling, but any such patterns would be very difficult to detect in a long-term study that included substantial variation in other physical conditions. A previous experiment in Jacoby Creek (Harvey et al. 2005) provides an opportunity to 

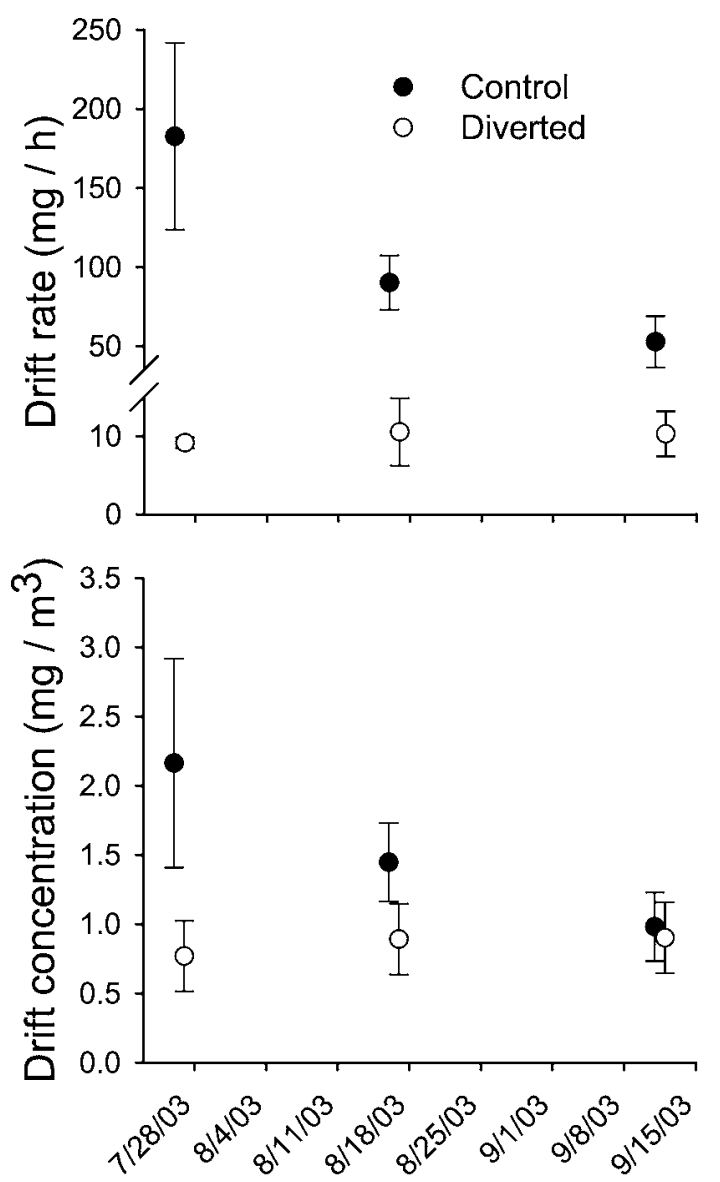

\section{Date}

FIGURE 5.-Drift concentration and rate in upper Jacoby Creek, California, experimental units with natural (control) and reduced (diverted) stream discharge. Drift samples were taken from $1 \mathrm{~h}$ before to $1 \mathrm{~h}$ after sunset. Drift rate estimates are based on unit-specific measurements of discharge taken within $5 \mathrm{~d}$ of the drift measurements. Points are slightly offset for clarity. Error bars indicate $\pm 1 \mathrm{SE} ; n=4$ for both treatments.

contrast growth in years with a smaller difference in streamflows than the one we imposed in this experiment. That study, conducted in 2001, included measurement of growth by individual rainbow trout during summer in 41 pools. The pools included in this study and those in the 2001 study held similar densities of fish (2003: $22.7 \mathrm{~g} / \mathrm{m} ; 2001: 25.5 \mathrm{~g} / \mathrm{m}$ ), and water temperature differed by less than $1{ }^{\circ} \mathrm{C}$ between years. Discharge during early September at a point within the study reaches of both years was about 2.5 times higher in 2003 than in 2001. Mean fish growth in the control units in the 2003 study exceeded growth in the 2001 study by 1.5 times. Although this contrast has several obvious limitations, it suggests that the results of our experiment should not be linearly extrapolated to smaller differences in streamflow.

The scale of observations and stream size differ between this study and that of Deegan et al. (1999), yet a relationship between water velocity and foraging energetics may be important to the results of both. In the Jacoby Creek experiment, the manipulation of discharge clearly affected the potential for drift feeding in that water velocities near zero characterized a much larger proportion of diverted units. Models of the energetics of similar-sized rainbow trout would predict that water velocities in the pool heads of control units were more profitable for rainbow trout than water velocities in the pool heads of the diverted units, given the body sizes of fish and assuming food availabilities similar to those in this experiment (e.g., Hill and Grossman 1993; Railsback and Harvey 2001). In two reaches of a tributary of the Connecticut River over 2 years, the mean mass of age-0 Atlantic salmon correlated positively with the availability of modelpredicted favorable foraging locations, which in turn were positively related to discharge (Nislow et al. 2004). In the Jacoby Creek experiment, the importance of flow characteristics for fish growth is further suggested by the apparent influence of pool head width on growth within the control treatment.

Models to assess the effects of water velocity and streamflow on foraging energetics commonly assume constant prey concentrations, but a wide variety of factors must influence the effect of streamflow on prey abundance. In the experiment at hand, the concentration of drift into control unit pools always equaled or exceeded the concentration of drift into diverted units. However, this result was influenced by unique aspects of the experimental setup. One might assume that the proportion of total drift entering the experimental units with reduced streamflow approximately equaled the proportion of streamflow that did not enter the diversion pipes; however, this might not have been true if drifting invertebrates avoided the pipes. In any case, a precise match in the effect on invertebrate input of a small-scale diversion of water and an equal reduction in flow on a much larger spatial scale seems unlikely. A further complication in this experiment is that food availability for fish in pools was influenced both by inputs into the units and by processes affecting invertebrate production and drift in the upstream riffle within each unit.

However, a general pattern of equal or greater prey concentrations with higher dry-season streamflows might be expected at larger spatial scales under nonexperimental conditions. Short-term field and 
laboratory experiments indicate that entry into the drift by benthic invertebrates increases with water velocity (Poff and Ward 1991; Borchardt 1993), as does the distance traveled by some drifting invertebrates (Allan and Feifarek 1989). If these mechanisms do not limit the abundance of potential drift organisms, they should provide more food to drift-feeding fishes at higher stream discharge.

This leads to the more general question: how does variation in flow affect the production of the invertebrate prey of many stream fishes? Secondary production of invertebrates in streams can be reduced after floods (Dudgeon 1999), but secondary production may also be reduced when base flows are relatively low. For example, Benbow et al. (2005) measured a difference between years in over-summer secondary production of aquatic insects occupying fast-water habitat in a Hawaii stream approximately equal to the difference between years in mean daily summer discharge, although the overall result included opposing responses by different taxa. Several mechanisms might contribute to a positive relationship between streamflow and the production of invertebrates. For example, a positive relationship between stream discharge and particulate organic matter, as documented by Golladay et al. (2000) across a relatively broad range of discharge for a southeastern U.S. stream, could provide a link between discharge and production along trophic pathways leading to fish. However, to our knowledge, generalizations about this issue remain elusive. Recognizing the capability of many drift-feeding stream fishes to also feed on the benthos, we believe the relation between streamflow and food availability for fish offers several avenues for useful future research.

In small streams such as Jacoby Creek, increasing dry-season discharge may improve habitat quality by reducing predation risk in addition to increasing foraging success. Uneven water surfaces may make fish less detectable by some predators (Allouche and Gaudin 2001). Thus, the upstream ends of the pools in the control units in this experiment may have provided both lower risk and greater feeding opportunities than did those in diverted units. Fish are rarely detected during daytime by observers on the streambanks of Jacoby Creek, suggesting that fish commonly sacrifice feeding opportunities by using cover to reduce their vulnerability to predators. Qualitative observations during this experiment suggest that fish in control units more often occupied microhabitats at the poolriffle transition than did fish in diverted units. In addition to the higher quality of these areas with higher discharge, a broader distribution of fish within units might also reduce the frequency of agonistic interactions.

This experiment suggests that changes in streamflow with only small changes in other aspects of physical habitat can lead to substantial changes in individual growth by salmonid fish. It also highlights the fact that because animals put energy into growth only after meeting the energetic demands of maintenance, relatively modest differences in total energy expenditure can lead to large differences in individual growth. The observed effect of discharge on growth strongly suggests that discharge variation could have important consequences for population dynamics. For resource managers dealing with the maintenance of salmonid populations in small streams, dry-season streamflow deserves attention in parallel with concerns about other physical features affected by human activities, such as the abundance of fine sediment (Suttle et al. 2004). However, the effects of dry-season streamflow on growth of stream fishes may vary widely across taxa and physical settings, in part the result of variation among fishes in swimming efficiency and utilization of drifting prey.

\section{Acknowledgments}

Travis Ayers provided field assistance and analyzed both the drift and diet samples. Steve Railsback assisted with the bioenergetics calculations. Mark Andre and the City of Arcata provided access to the study site. The manuscript benefited from reviews by Larry Brown, Tom Lisle, and Frank McCormick.

\section{References}

Allan, J. D., and B. P. Feifarek. 1989. Distances traveled by drifting mayfly nymphs: factors influencing return to the substrate. Journal of the North American Benthological Society 8:322-330.

Allouche, S., and P. Gaudin. 2001. Effects of avian predation threat, water flow, and cover on growth and habitat use by chub, Leuciscus cephalus, in an experimental stream. Oikos 94:481-492.

Benbow, M. E., M. D. McIntosh, A. J. Burky, and C. M. Way. 2005. The influence of stream flow reduction on the energetics of endemic Hawaiian torrenticolous aquatic insects, Telmatogeton Schiner and Procanace Hendel. Journal of Aquatic Insect Conservation 9:175-185.

Borchardt, D. 1993. Effects of flow and refugia on drift loss of benthic macroinvertebrates: implications for habitat restoration in lowland streams. Freshwater Biology 29:221-227.

Deegan, L. A., H. E. Golden, C. J. Harvey, and B. J. Peterson. 1999. Influence of environmental variability on the growth of age- 0 and adult Arctic grayling. Transactions of the American Fisheries Society 128:1163-1175.

Dudgeon, D. 1999. Patterns of variation in secondary production in a tropical stream. Archiv für Hydrobiologie 144:271-281. 
Golladay, S. W., K. Watt, S. Entrekin, and J. Battle. 2000. Hydrologic and geomorphic controls on suspended particulate organic matter concentration and transport in Ichawaynochaway Creek, Georgia, USA. Archiv für Hydrobiologie 149:655-678.

Gomi, T., R. C. Sidle, and J. S. Richardson. 2002. Understanding processes and downstream linkages of headwater systems. BioScience 52:905-916.

Guyette, R. P., and C. F. Rabeni. 1995. Climate response among growth increments of fish and trees. Oecologia 104:272-279.

Hakala, J. P., and K. J. Hartman. 2004. Drought effect on stream morphology and brook trout (Salvelinus fontinalis) populations in forested headwater streams. Hydrobiologia 515:203-213.

Hanson, P. C., T. B. Johnson, D. E. Schindler, and J. F. Kitchell. 1997. Fish Bioenergetics 3.0. University of Wisconsin Sea Grant Institute, Sea Grant Technical Report, Madison.

Harvey, B. C. 1998. Influence of large woody debris on retention, immigration, and growth of coastal cutthroat trout (Oncorhynchus clarki clarki) in stream pools. Canadian Journal of Fisheries and Aquatic Sciences 55:1902-1908.

Harvey, B. C., and A. J. Stewart. 1991. Fish size and habitat depth relationships in headwater streams. Oecologia 87:336-342.

Harvey, B. C., J. L. White, and R. J. Nakamoto. 2005. Habitat-specific biomass, survival, and growth of rainbow trout (Oncorhynchus mykiss) during summer in a small coastal stream. Canadian Journal of Fisheries and Aquatic Sciences 62:650-658.

Heggenes, J., and R. Borgstrøm. 1988. Effect of mink, Mustela vison Schreber, predation on cohorts of juvenile Atlantic salmon, Salmo salar L., and brown trout, S. trutta L., in three small streams. Journal of Fish Biology 33:885-894.

Hicks, B. J., R. L. Beschta, and R. D. Harr. 1991. Long-term changes in streamflow following logging in western
Oregon and associated fisheries implications. Water Resources Bulletin 27:217-226.

Hill, J., and G. D. Grossman. 1993. An energetic model of microhabitat use for rainbow trout and rosyside dace. Ecology 74:685-698.

Keppeler, E. T., and R. R. Ziemer. 1990. Logging effects on streamflow: water yield and summer low flows at Caspar Creek in northwestern California. Water Resources Research 26:1669-1679.

May, C. L., and D. C. Lee. 2004. The relationships among inchannel sediment storage, pool depth, and summer survival of juvenile salmonids in Oregon Coast Range streams. North American Journal of Fisheries Management 24:761-774.

Nislow, K. H., A. J. Sepulveda, and C. L. Folt. 2004. Mechanistic linkage of hydrologic regime to summer growth of age-0 Atlantic salmon. Transactions of the American Fisheries Society 133:79-88.

Novinger, D. C., and F. J. Rahel. 2003. Isolation management with artificial barriers as a conservation strategy for cutthroat trout in headwater streams. Conservation Biology 17:772-781.

Poff, N. L., and J. V. Ward. 1991. Drift responses of benthic invertebrates to experimental streamflow variation in a hydrologically stable stream. Canadian Journal of Fisheries and Aquatic Sciences 48:1926-1936.

Railsback, S. F., and B. C. Harvey. 2001. Individual-based model formulation for cutthroat trout, Little Jones Creek, California. U.S. Forest Service, Pacific Southwest Research Station, General Technical Report PSW-GTR182, Albany, California.

Railsback, S. F., and K. A. Rose. 1999. Bioenergetics modeling of stream trout growth: temperature and food consumption effects. Transactions of the American Fisheries Society 128:241-256.

Suttle, K. B., M. E. Power, J. M. Levine, and C. McNeely. 2004. How fine sediment in riverbeds impairs growth and survival of juvenile salmonids. Ecological Applications 14:969-974. 